\title{
PEMEKATAN LATEKS KEBUN SECARA CEPAT DENGAN PROSES SENTRIFUGASI PUTARAN RENDAH
}

\author{
Rapid Concentration of Field Latex by Low Speed Centrifugation Process \\ Henry PRASTANTO, Asron F FALAAH, dan Dadi R MASPANGER \\ Pusat Penelitian Karet \\ Jalan Salak No 1 Bogor 16151 \\ Email : maspanger@yahoo.com
}

Diterima : 25 April 2014 / Direvisi : 18 Mei 2014 / Disetujui : 9 Juli 2014

\begin{abstract}
The objective of this research were to study the combination of creaming and centrifugation process, to increase the creaming rate by using low speed centrifuge machine. Concentrated latex is one kind of commercial product from rubber industry and still produced by big factories, in general it is prepared by high capital cost centrifugation machine, and it becomes a major obstacle for small scale industries to participate in concentrated latex industry. To produce concentrated latex from field latex can be carried out by high speed centrifugation, (9000$15000 \mathrm{rpm}$ ) and by creaming process. Creamed latex, concentrated latex, prepared by using creaming agents i.e. CMC and alginate, in batch tank for 1-2 weeks and this creaming process very slow rate, thereby requiring lot of time, causing concentrated latex production by creaming technique not popular at industries. In this study a simple sentrifuge machine had been designed and it was expected to be feasible for small medium scale industries, driven by electromotor $5 \mathrm{HP}$ with a maximum speed of $5000 \mathrm{rpm}$ and had a capacity of about 5-6 L field latex. To produce creamed latex quickly about $5 \mathrm{~L}$ per hour, CMC as a creaming agent was added to the field latex with doses of 0 to $0.2 \%$. Centrifugation time varied for 0 to 60 minutes at a speed of $5000 \mathrm{rpm}$. The results showed that the optimum conditions to obtain the Dry Rubber Content above $60 \%$ was obtained at a dosage of only $0.1 \%$ CMC with a time of centrifugation for 45 min.
\end{abstract}

Keywords: Creamed latex, low speed sentrifugation, CMC, Dry Rubber Content

\section{Abstrak}

Tujuan dari penelitian ini adalah untuk mempelajari kombinasi proses pendadihan dan sentrifugasi, untuk meningkatkan kecepatan pendadihan dengan menggunakan mesin sentrifugasi kecepatan rendah. Lateks pekat adalah salah satu jenis produk komersial dari industri karet dan masih diproduksi oleh pabrik besar, umumnya dibuat dari mesin sentrifugasi yang biaya investasinya mahal, Hal inilah yang menjadi hambatan bagi industri kecil untuk terjun dalam industri lateks pekat. Untuk memproduksi lateks pekat dari lateks kebun dapat dilakukan dengan proses sentrifugasi putaran tinggi (9000-15000 rpm) dan pendadihan. Lateks dadih adalah lateks pekat, dibuat dengan menggunakan bahan pendadih misalnya CMC dan alginat dalam tangki secara batch selama 1-2 minggu dan proses pendadihan ini kecepatan pemisahannya sangat lambat, sehingga membutuhkan waktu yang lama, akibatnya lateks pekat yang diproduksi dengan teknik pendadihan tidak populer di industri. Dalam penelitian ini sebuah mesin sentrifugasi didisain sederhana dan diharapkan layak digunakan oleh industri kecil menengah, digerakkan dengan motor 5 HP dengan kecepatan maksimum 5000 rpm dan mempunyai kapasitas sekitar 5-6 liter lateks kebun. Untuk memproduksi lateks dadi sekitar 5 liter lateks kebun per jam, bahan pendadih CMC ditambahkan ke lateks kebun dengan dosis 0 sampai $0,2 \%$. Waktu sentrifugasi divariasikan selama 0 sampai 60 menit pada kecepatan 5000 rpm. Hasil penelitian menunjukkan, kondisi optimum untuk memperoleh kadar karet kering di atas 60\% diperoleh pada dosis CMC hanya $0,1 \%$ dengan waktu sentrifugasi selama 45 menit.

Kata kunci: Lateks dadih, sentrifugasi putaran rendah, $\mathrm{CMC}$, kadar karet kering

\section{PENDAHULUAN}

Berdasarkan data Gapkindo (2013) ekspor lateks pekat mengalami kenaikan dari 7,6 metrik ton pada tahun 2007 hingga mencapai 12,9 metrik ton pada 2010 . Namun pada periode 2011-2012 ekspor lateks pekat mengalami penurunan sekitar $15-20 \%$, walaupun demikian pangsa pasar lateks pekat tetap stabil karena barang- 
barang seperti karet busa, kondom, sarung tangan, selang kateter, selang transfusi, lem, balon dan barang-barang tipis/transparan lainnya hanya dapat dibuat dari lateks pekat (Maspanger, 2005). Lateks pekat saat ini banyak diproduksi oleh pabrik besar. Sedangkan produksi lateks pekat di tingkat petani masih terbatas karena petani lebih memilih menghasilkan bokar berupa lum atau slab yang tidak memerlukan teknologi rumit dan investasi yang besar.

Lateks pekat di Indonesia diproduksi menggunakan metode sentrifugasi dan pendadihan. Lateks pekat sentrifugasi diproduksi menggunakan mesin sentrifugasi yang diputar pada 9000-15000 $\mathrm{rpm}$. Putaran yang tinggi akan menghasilkan gaya sentrifugal yang besar untuk memisahkan sebagian air untuk kemudian diperoleh lateks pekat dengan kadar karet kering berkisar $55-60 \%$. Metode sentrifugasi banyak digunakan oleh pabrik lateks pekat karena dapat memekatkan lateks dengan waktu relatif singkat dan mutu lateksnya lebih baik bila dibandingkan dengan pendadihan. Sedangkan kelemahan metode sentrifugasi adalah membutuhkan biaya investasi yang lebih besar bila dibandingkan dengan pendadihan.

Produksi lateks pekat dengan metode pendadihan kebanyakan dilakukan oleh petani atau IKM. Produksi lateks pekat dengan metode pendadihan dilakukan dengan menambahkan sejumlah bahan pendadih yang mampu memisahkan partikel karet dengan air. Menurut Sugianto (1988) umumnya bahan pendadih yang digunakan antara lain $\mathrm{NH}_{3}$-Alginat atau NaAlginat dan carboxy methyl cellulosa (CMC). Penelitian yang dilakukan United State Rubber Company (1936) menggunakan tanaman jenis Eucaesalpinieae dapat menghasilkan lateks pekat dengan KKK $66 \%$, sementara Hauser dan Bradley (1941) menggunakan amonium alginat dan locus bean gum sebagai bahan pendadih yang menghasilkan lateks pekat dengan KKK 50$60 \%$.

Metode pendadihan tidak memerlukan biaya investasi besar, karena hanya memerlukan bahan pendadih dan peralatan sederhana seperti tangki tempat pendadihan, pengaduk dan penampung hasil. Namun demikian metode pendadihan memerlukan waktu cukup lama sekitar 2-3 minggu untuk memisahkan fase air hidrokarbon karet. Lateks pekat yang berasal dari proses pendadihan murni, mutunya cenderung kurang baik karena banyak mengandung campuran bahan pendadih. Selain itu barang jadi lateks tipis dari bahan baku lateks dadih seperti sarung tangan, balon dan kondom kualitasnya masih kurang baik (Nobel, 1983).

Pendekatan teknologi yang mudah dan murah sangatlah diperlukan, selain menjamin ketersediaan bokar lateks pekat ditingkat petani, juga dapat memberikan nilai tambah pendapatan petani untuk memproduksi lateks pekat dengan biaya produksi rendah. Salah satu metode yang dinilai efektif untuk menghasilkan lateks pekat adalah dengan mengkombinasikan metode pendadihan dan sentrifugasi. Hasil penelitian yang dilakukan oleh Maspanger (2007), yaitu menggunakan putaran mesin sentrifugasi skala laboratorium dengan putaran 2500 rpm dan bahan pendadih CMC sebesar $0,15 \%$ dengan waktu maturasi $36-$ 60 jam, yang menghasilkan kualitas lateks pekat yang setara dengan lateks pekat hasil pendadihan konvensional 14 hari. Kombinasi proses ini menghasilkan gaya sentrifugal tetap besar melalui penambahan bahan pendadih dalam lateks yang dapat meningkatkan berat partikel, sehingga menyebabkan gaya sentrifugal tetap besar, meskipun kecepatan putaran mesin sentrifugasi rendah. Dengan mengoperasikan mesin sentrifugasi pada putaran rendah dapat menurunkan biaya operasional produksi lateks pekat.

Penelitian ini bertujuan untuk mengembangkan teknologi proses pembuatan lateks pekat yang mampu diterapkan ditingkat petani maupun IKM dengan mengkombinasikan proses pendadihan dan sentrifugasi putaran rendah. Penelitian ini meminimalkan pemakaian bahan pendadih yang menyebabkan kualitas lateks pekat tidak baik serta menggunakan sentrifugasi dengan putaran rendah (di bawah 9000 rpm). Dengan mengkombinasikan kedua proses tersebut, maka proses produksi lateks pekat berlangsung cepat sehingga menghemat waktu produksi serta biaya lebih murah. 


\section{BAHAN DAN METODE}

Penelitian ini dilakukan di Pabrik Percobaan dan Laboratorium Pengujian Pusat Penelitian Karet di Bogor periode April - Oktober 2013. Bahan baku utama yang digunakan dalam penelitian ini yaitu lateks kebun yang diperoleh dari kebun Ciomas Bogor, untuk bahan pendadih digunakan carboxy methyl cellulosa (CMC) karena biasa dipakai oleh petani dan mudah didapatkan. Lateks kebun diberi bahan pengawet amonia dengan dosis $0,6 \%$, kemudian diperam $1 \mathrm{x}$ 24 jam untuk mengendapkan lumpur yang banyak mengandung (ion $\mathrm{Mg}^{++}$), karena lateks yang masih mengandung terlalu banyak ion $\mathrm{Mg}^{++}$dapat mengalami penurunan mutu lebih cepat selama penyimpanan (Handoko, 1990). Lateks dipisahkan dari lumpur dan kemudian ditampung dalam wadah. Proses pemekatan lateks dilakukan menggunakan mesin sentrifugasi (Gambar 1) yang dilengkapi motor penggerak berkekuatan $1 \mathrm{HP}$. Mesin sentrifugasi tersusun dari 8 tabung untuk tempat botol yang berisi lateks.
Dalam penelitian ini kadar karet kering lateks kebun dibuat sama untuk setiap perlakuan yaitu sebesar 30\%. Larutan CMC $1 \%$ ditambahkan dalam lateks kebun dengan variasi kadar CMC sebesar $0 \%$, $0,05 \%, 0,10 \%, 0,15 \%$ dan $0,2 \%$. Lateks yang telah ditambahkan CMC diisikan ke dalam botol berkapasitas $600 \mathrm{ml}$, dan selanjutnya botol tersebut dimasukkan ke dalam tabung yang terdapat pada mesin sentrifugasi. Kecepatan putaran mesin sentrifugasi diatur pada $5000 \mathrm{rpm}$, sedangkan waktu sentrifugasi divariasikan selama $15,30,45$, dan 60 menit.

Setelah proses sentrifugasi lateks dipisahkan dari serumnya. Lateks kemudian diuji Kadar Karet Kering (KKK). Optimasi dalam penelitian ini dilakukan berdasarkan waktu sentrifugasi dan dosis CMC yang ditambahkan dalam lateks. Pengamatan dilakukan dalam penelitian ini yaitu terhadap serum dan nilai KKK yang dihasilkan dari setiap variabel percobaan.

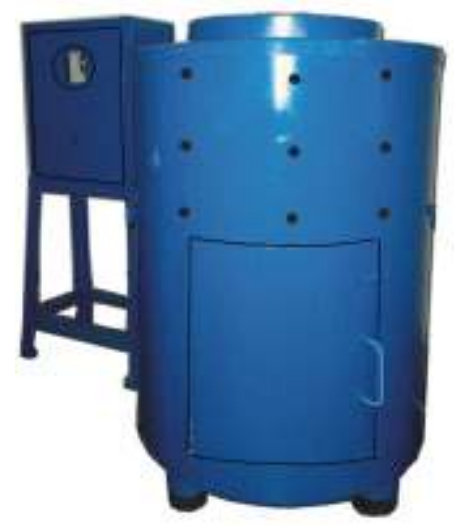

Gambar 1. Mesin sentrifugasi putaran rendah

Figure 1. Low speed centrifugation machine

\section{HASIL DAN PEMBAHASAN}

Penggunaan CMC sebagai bahan pendadih umumnya digunakan dosis sebesar 0,298\%, tergantung KKK dan kadar amonia yang ditambahkan ke dalam lateks (Twiss dan Carpenter, 1939). Penelitian ini memilih menggunakan CMC, karena senyawa tersebut hanya sedikit pengaruhnya terhadap sifat barang jadi lateks yang dihasilkan.
Proses pendadihan mengikuti Hukum Stokes (Blackley, 1966) yang dinyatakan dalam Persamaan 1, dimana kecepatan gerakan partikel dalam cairan salah satunya dipengaruhi oleh ukuran partikel.

$$
v=\frac{g D^{2}(\rho-\rho s)}{18 \mu}
$$


Dimana:

$$
\begin{array}{ll}
v \quad= & \text { kecepatan gerakan air ke bawah }= \\
& \text { kecepatan gerak partikel karet ke } \\
& \text { atas } \\
D & \text { diameter partikel karet } \\
g & =
\end{array}
$$

Penambahan bahan pendadih dalam lateks kebun menyebabkan adanya aglomerasi atau bergabungnya pertikel karet menjadi berukuran lebih besar. Berdasarkan Persamaan (1) maka semakin besar ukuran partikel karet, gerakannya akan semakin cepat. Dosis bahan pendadih akan mempengaruhi kecepatan penggabungan partikel karet dan ukuran aglomerasi yang terbentuk. Semakin tinggi kadar bahan pendadih pada batas tertentu akan semakin meningkatkan ukuran aglomerasinya. Namun penambahan bahan pendadih ini juga akan diiringi dengan peningkatan viskositas cairan.

Menurut Persamaan 1 viskositas akan mempengaruhi kecepatan gerakan partikel. Penambahan bahan pendadih yang berlebihan akan meningkatkan viskositas air, sehingga jika terlalu berlebihan justru akan dapat menurunkan kecepatan gerakan partikel karet. Oleh karena itu perlu diketahui batasan dosis bahan pendadih agar tercapai kecepatan yang optimal.

Pemisahan partikel dapat dipercepat dengan adanya gaya sentrifugal yang dirumuskan sebagai berikut (Perry dan Chilton, 1973).

$F=\frac{W}{g} r \omega^{2}$

Dimana:

$$
\begin{array}{ll}
F & =\text { gaya sentrifugal } \\
W & =\text { berat partikel } \\
g & =\text { percepatan gravitasi } \\
r & =\text { radius putaran } \\
\omega & =\text { kecepatan sudut }
\end{array}
$$

Besar gaya sentrifugal yang digunakan untuk pemisahan partikel karet menurut Persamaan 2 dipengaruhi oleh berat partikel dan kecepatan sudut putaran. Semakin besar berat partikel maka kecepatan sudut yang diperlukan akan semakin rendah. Sedangkan pengaruh ukuran partikel yang terpisah dalam pemisahan dengan mesin sentrifugal dinyatakan dalam persamaan berikut (Blackley, 1966)

$x_{R}=\sqrt{\left(\frac{18 \mu}{(\sigma-\rho) \omega^{2} t}\right) \log \frac{R_{0}}{R}}$

Dimana:

$x_{R} \quad=$ diameter minimal partikel yang
terpisah
$\mu \quad=$ viskositas cairan
$\sigma \quad=$ densitas air
$\rho \quad=$ densitas partikel karet
$\omega \quad=$ kecepatan sudut putaran mesin
$t_{0} \quad=$ sentrifugasi
$R_{0} \quad=\quad$ Radius posisi partikel mula-mula
$\quad$ waktu tertentu (t)

Berdasarkan Persamaan 3 perbedaan densitas yang cukup besar tidak membutuhkan kecepatan putaran yang tinggi, begitu juga ukuran partikel yang lebih besar tidak membutuhkan kecepatan yang terlalu tinggi. Penambahan CMC yang dapat menyebabkan pertambahan ukuran partikel sehingga dapat menurunkan kecepatan sudut minimal agar terjadi pemisahan.

Hasil yang diperoleh dalam penelitian ini menunjukkan bahwa proses pemekatan lateks dengan menggunakan metode kombinasi pendadihan dan sentrifugasi putaran rendah telah berhasil memisahkan lateks dengan serumnya dengan putaran yang lebih rendah yaitu 5000 rpm. Secara umum kecepatan putar mesin sentrifugasi yang dipakai secara komersial adalah 9000 $15000 \mathrm{rpm}$. Fraksi lateks berada dipermukaan atas dan fraksi serum berada 


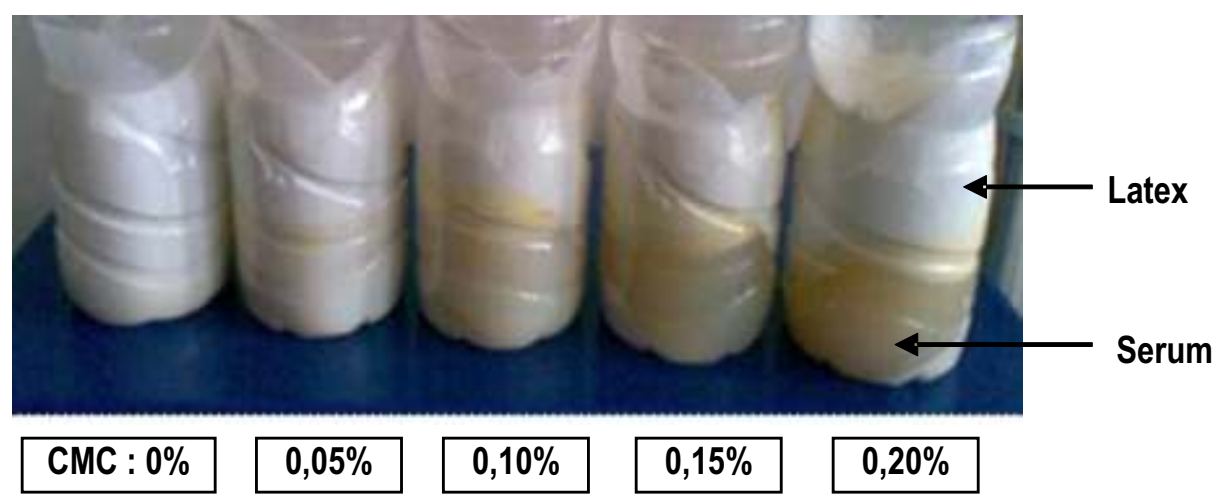

Gambar 2. Pemisahan lateks dan serum setelah proses sentrifugasi selama 60 menit pada berbagai dosis CMC

Figure 2. Latex and serum separation after centrifugation process for 60 minutes at various CMC dosage

di bagian bawah. Kejernihan serum dari lateks pekat yang dihasilkan meningkat seiring dengan meningkatnya dosis CMC yang ditambahkan. Ini artinya ukuran aglomerasi partikel karet semakin besar. Pada dosis 0,05\%, serum yang dihasilkan masih berwarna putih keruh, menandakan serum belum terpisah sempurna karena ukuran partikel karet masih terlalu kecil. Pada dosis $0,10 \%$ serum mulai terlihat jernih yang menandakan kadar karet di dalam serum tersebut semakin rendah. Sedangkan dosis CMC di atas 0,10\% serum yang dihasilkan lebih banyak dan berwarna bening. Gambar 2 menyajikan hasil percobaan setelah proses sentrifugasi.

Kejernihan serum tidak menjamin kadar karet lateks menjadi lebih tinggi. Oleh karena itu perlu dilakukan pengukuran kadar karet kering lateks. Hasil pengujian kadar karet kering lateks disajikan dalam Tabel 1 berikut.
Pada percobaan dosis CMC $0,10 \%$ dan $0,15 \%$ dengan waktu sentrifugasi $30-60$ menit telah mencapai nilai KKK di atas 50\%, namun demikian dosis CMC 0,10\% dengan waktu sentrifugasi 45 menitlah yang menghasilkan nilai KKK di atas $60 \%$. Kadar CMC di bawah 0,10\% diperoleh KKK di bawah $60 \%$, karena serum berwarna putih keruh yang menandakan pemisahan belum maksimal.

Kadar CMC di atas 0,15\% menghasilkan serum yang berwarna bening, namun nilai KKK lateks pekat mengalami penurunan. Hal ini dikarenakan kadar CMC yang terlalu tinggi akan menyebabkan viskositas lateks menjadi lebih tinggi sehingga pergerakan karet selama pemisahan atau sentrifugasi menjadi lebih lambat. Sedangkan pada Gambar 3 terlihat pola kurva KKK yang cenderung naik, namun kemudian menurun seiring dengan meningkatnya dosis CMC.

Tabel 1. Kadar Karet Kering lateks pekat

Table 1. Dry Rubber Content of concentrated latex

\begin{tabular}{cccccc}
\hline $\begin{array}{c}\text { Waktu sentrifugasi, } \\
\text { (menit) }\end{array}$ & \multicolumn{5}{c}{$\begin{array}{c}\text { Dosis CMC } \\
\text { CMC dosage } \\
(\%)\end{array}$} \\
\cline { 2 - 6 } $\begin{array}{c}\text { Centrifugation times, } \\
\text { (minutes) }\end{array}$ & 0 & 0,05 & 0,10 & 0,15 & 0,20 \\
\hline 0 & 30 & 30 & 30 & 30 & 30 \\
15 & 31,23 & 48,57 & 51,53 & 46,40 & 39,45 \\
30 & 40,78 & 58,57 & 55,24 & 62,00 & 45,47 \\
45 & 40,89 & 59,26 & 63,37 & 53,30 & 48,73 \\
60 & 52,59 & 61,18 & 59,82 & 61,93 & 47,14 \\
\hline
\end{tabular}




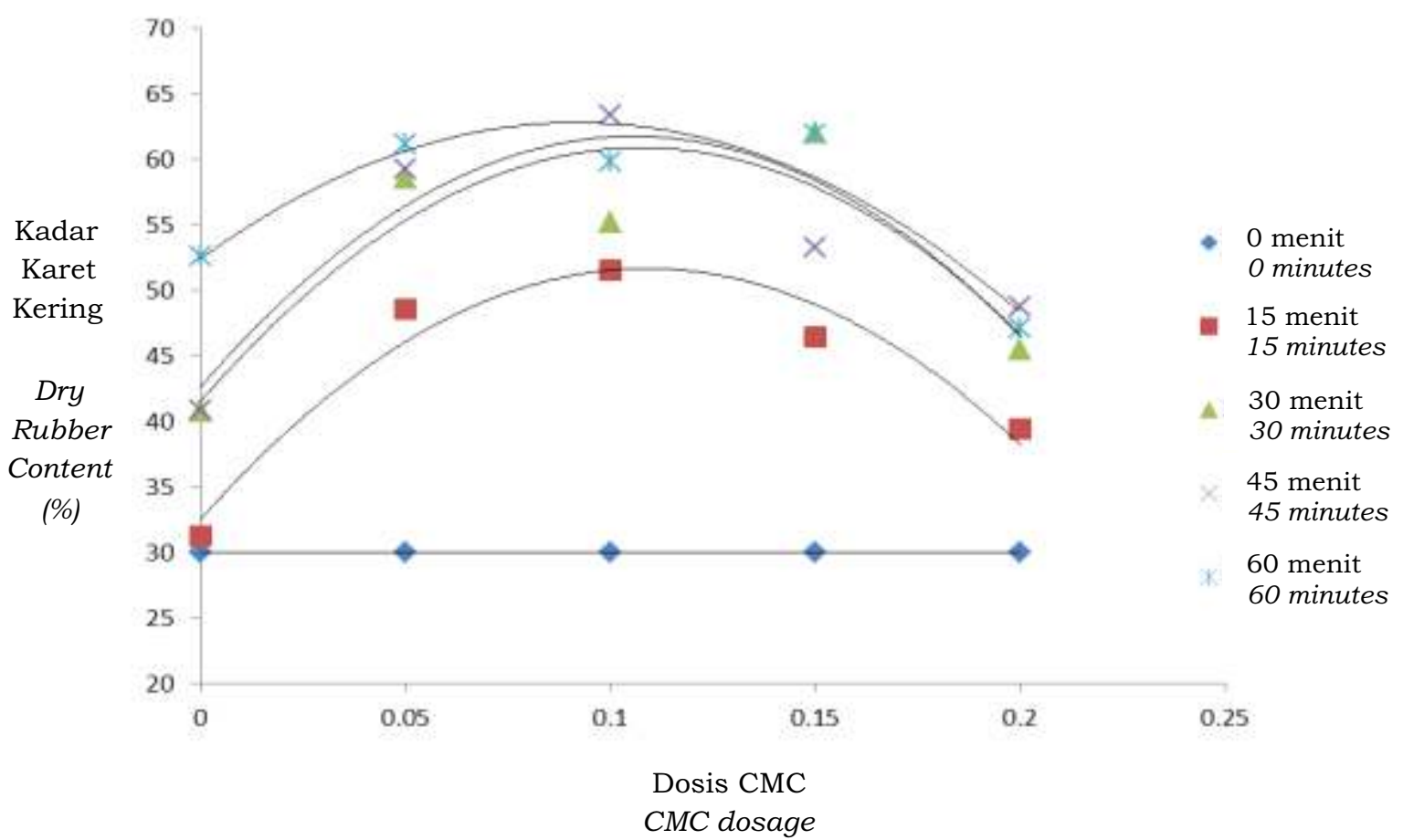

$(\%)$

Gambar 3. Pengaruh CMC terhadap kadar karet kering lateks pada berbagai waktu sentrifugasi

Figure 3. The effect of CMC on the dry rubber content of latex at various centrifugation times

Kenaikan kadar karet kering lateks secara drastis terjadi pada awal sentrifugasi. Hal ini ditunjukkan dalam Gambar 4 yaitu pada konsentrasi CMC $0,1 \%$. Pada sentrifugasi selama 15 menit sudah terjadi kenaikan kadar karet kering dari 30\% menjadi 55,24\%. Untuk mencapai kadar di atas $60 \%$ diperlukan waktu paling tidak selama 45 menit. Sentrifugasi lebih dari 45 menit akan tidak ekonomis lagi karena kadar karet kering lateks sudah tidak mengalami kenaikan yang signifikan.

Persyaratan mutu lateks pekat yang dikehendaki konsumen (cenderung berbeda dari satu pabrik ke pabrik lainnya) biasanya banyak didasarkan pada pengalaman selama produksi (Suparto, 2007). Mutu lateks pekat dengan metode sentrifugasi putaran rendah dengan penambahan sedikit bahan pendadih ini perlu dikaji lebih lanjut dalam hal mutu lateks secara lebih lengkap, karena mutu lateks pekat tidak hanya ditentukan dari kadar karet keringnya saja. Penambahan sedikit bahan pendadih mestinya akan menghasilkan lateks pekat dengan mutu yang lebih baik daripada mutu lateks dadih. Namun jika dibandingkan dengan mutu lateks pekat sentrifugasi komersial yang sekarang sudah ada di pasaran tentunya akan lebih rendah.

Alat sentrifugasi lateks pekat dengan putaran rendah ini dapat digunakan untuk pembuatan lateks pekat. Hasil penelitian dengan alat ini selanjutnya dapat digunakan sebagai dasar dalam pembuatan alat sentrifugasi yang skalanya lebih besar atau bahkan digunakan sebagai dasar untuk pembuatan alat sentrifugasi putaran rendah kontinyu. Dengan putaran yang lebih rendah maka diharapkan harga mesin sentrifugasi dapat ditekan dan dapat dijangkau oleh masyarakat atau industri kecil menengah. 


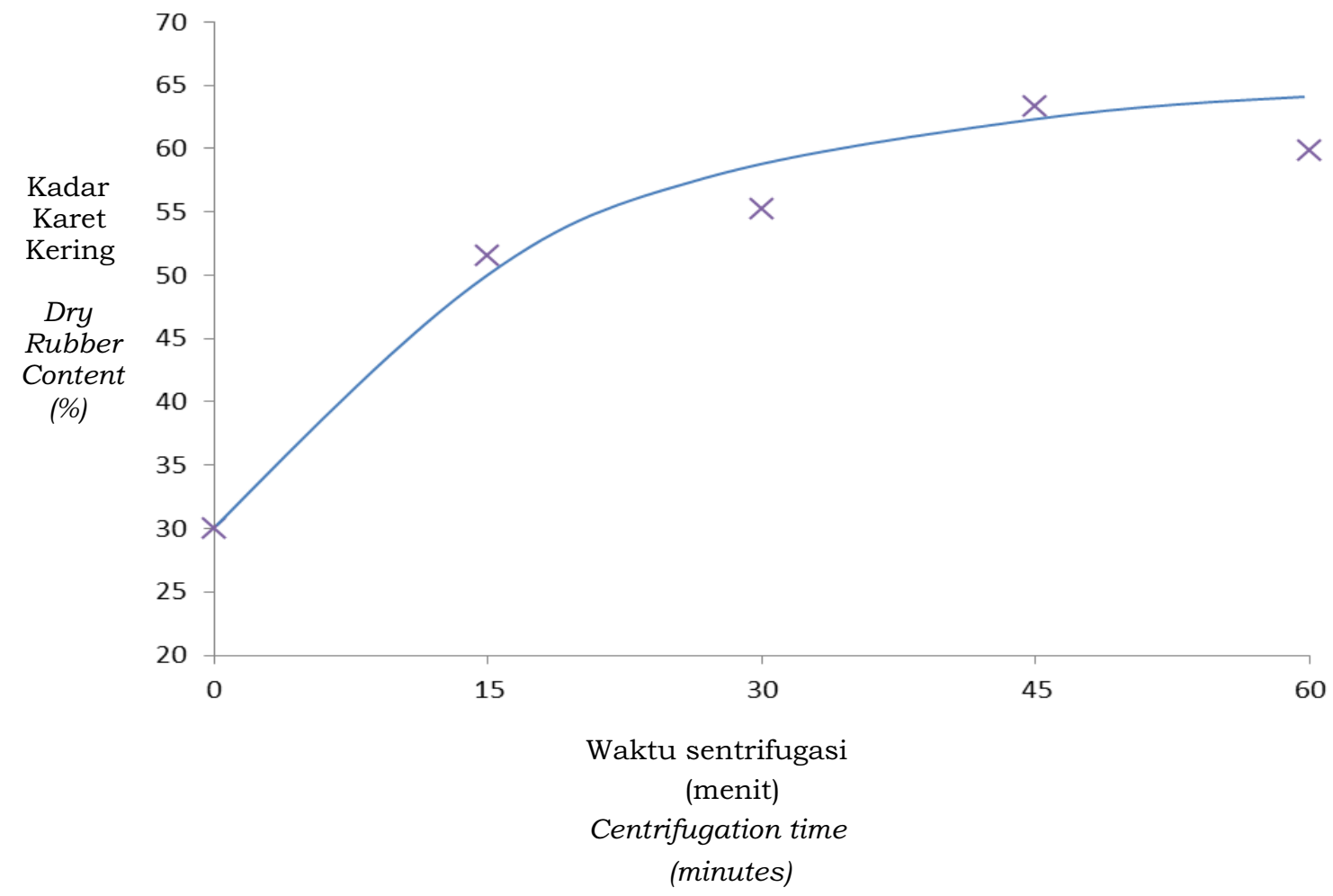

Gambar 4. Pengaruh lama sentrifugasi terhadap kadar karet kering lateks pada dosis CMC $0,1 \%$

Figure 4. The effect of centrifugation times on the dry rubber content of latex at CMC $0,1 \%$ dosage

\section{KESIMPULAN DAN SARAN}

Pembuatan lateks pekat dengan metode sentrifugasi putaran rendah yaitu 5000 rpm dapat dilakukan dengan penambahan sedikit bahan pendadih. Penambahan bahan pendadih yang terlalu besar dapat meningkatkan viskositas cairan sehingga memperlambat proses pemekatan. Dosis bahan pendadih CMC optimum adalah $0,1 \%$ dan waktu sentrifugasi selama 45 menit. Teknologi ini bila dibandingkan dengan pendadihan secara konvensional dapat menurunkan kadar CMC dari 0,298\% menjadi $0,1 \%$ dan mempercepat waktu pendadihan dari 2 minggu menjadi 45 menit. Penelitian ini dapat digunakan sebagai landasan untuk perancangan alat sentrifugasi secara batch yang lebih besar atau secara kontinyu.

\section{DAFTAR PUSTAKA}

Blackley, D. C. 1966. High Polymer Latices Fundamental Principles. McLaren \& Sons Ltd, London.

Gabungan Perusahaan Karet Indonesia (Gapkindo), 2013. Ekspor Karet Alam Indonesia Menurut Jenis Mutu. www.gapkindo.org., diakses tanggal 8 April 2014.

Handoko, Bambang. 1990. Pengaruh Penambahan Diamonium Hidrogen Fosfat (DAP) Ke Dalam Lateks Kebun Berkadar Magnesium Tinggi Terhadap Mutu Lateks Pekatnya. Menara Perkebunan 58 (4): 122 - 126.

Hauser, E. A and Bradley D. J. 1941. Creaming of Rubber Latex. Journal of Industrial and Engineering Chemistry 33 (1): $127-130$. 
Maspanger, D. R. 2005. Tinjauan Berbagai Sistem Pemekatan Lateks Dan Kemungkinan Aplikasi Pengeringan Beku Untuk Meningkatkan Konsentrasi Lateks Hevea. Laporan Teknis Intern Tahun 2005. Balai Penelitian Teknologi Karet Bogor, Bogor

Maspanger, D. R. 2007. Pembuatan Lateks Dadih Dengan Proses Sentrifugasi Putaran Rendah dan Kualitas Barang Jadi Karetnya. Agritech 27(3): 124 129.

Nobel, J.R. 1983. Latex in Industry. Rubber Age, New York.

Perry, R. H. and C.H. Chilton. 1973. Chemical Engineers Handbook, 5th ed. Mc Graw-Hill, Kogakusha.
Sugianto, S. 1988. Perbedaan Beberapa Sifat Fisika Vulkanisat Asal Lateks Pusingan dan Lateks Dadih. Menara Perkebunan 56 (3): $80-83$.

Suparto, Dadang. 2007. Pemantauan Kesesuaian Mutu Lateks Pekat Untuk Barang Jadi Lateks. Warta Perkaretan. $26(2): 62-68$

Twiss, D. F. and A. S Carpenter. 1939. The Compotition and Characteristics of the Rubber in Hevea Latex. Rubber Chemistry and Technology 12(3) : 448 464.

United States Rubber Company, assigne., 1936. Improvement in or Relating to Creaming of Rubber Latex. Great Britain Patent GB 448203. 